\title{
Assessing the N Cycling Ecosystem Function-Processes and the Involved Functional Guilds upon Plant Litter Amendment in Lower Himalaya
}

\author{
Tahir Zaman ${ }^{1}$, Akhtar Iqbal ${ }^{1}$, Areeba Shaukat ${ }^{1}$, Rashid Nazir ${ }^{1}$, Arshid Pervez ${ }^{1}$, \\ Muhammad Bilal', Faridullah', Muhammad Rizwan², Shafaqat Ali ${ }^{2,3 *}$, \\ Saad Alkahtani ${ }^{4}$, Mohamed M. Abdel-Daim ${ }^{4,5}$, Farhan Hafeez ${ }^{1 * *}$ \\ ${ }^{1}$ Department of Environmental Sciences, COMSATS University Islamabad, Abbottabad Campus, \\ Tobe Camp University Road Abbottabad 22060 Pakistan \\ ${ }^{2}$ Department of Environmental Sciences and Engineering, Government College University, Faisalabad, 38000, Pakistan \\ ${ }^{3}$ Department of Biological Sciences and Technology, China Medical University, Taichung 40402, Taiwan \\ ${ }^{4}$ Department of Zoology, College of Science, King Saud University, P.O. Box 2455, Riyadh 11451, Saudi Arabia \\ ${ }^{5}$ Pharmacology Department, Faculty of Veterinary Medicine, Suez Canal University, Ismailia 41522, Egypt
}

Received: 10 April 2020

Accepted: 23 May 2020

\begin{abstract}
Nitrogen $(\mathrm{N})$ cycling ecosystem function is crucial in primary productivity but also carry various ecological implications such as $\mathrm{N}$ losses to environment. In mountainous soil ecosystems, this important function beside soil characteristics is dependent on the litter produced through plant decay which may play a critical role in shaping the hosted soil microbial communities such as those involved in $\mathrm{N}$ cycling processes. This study aims at investigating the effects of plant litter amendment, believed to reduce the nitrogen leaching and improve soil health, on nitrogen cycling microbial communities and processes using litterbag approach at field station of COMSATS, Abbottabad. Plant litter collected from the stands of Pine (Pinus wallichiana) and understory Indigo shrub commonly known as Indigo Himalayan (Indigofera heterentha (Fabaceae) wall), near Abbottabad, native to the lower Himalaya, were applied to indigenous loamy soil in four treatments (i.e. Control, Pine, Indigo and Pine + Indigo). The $\mathrm{N}$ cycling processes (involved in nitrous oxide GHG emissions, potential nitrification activity PNA and denitrification enzyme activity - DEA), through measuring enzymes activities and the abundances of nitrifying - amoA (ammonia oxidizing bacteria - AOB, ammonia oxidizing archaea - AOA) and denitrifying functional guilds (nirS, nosZ) were determined using quantitative PCRs by targeting their corresponding genes. The results revealed that the plant litter significantly influenced both nitrification and denitrification but also the size of microbial communities involved in these two
\end{abstract}

\footnotetext{
*email co-correspondence: shafaqataligill@yahoo.com
}

**email correspondence: drfarhan@cuiatd.edu.pk 
processes. The number of archaeal and bacterial amoA gene copies increased with the application of Indigofera treatment with AOA size higher than the AOB with correlation matrix revealing that AOB were dominant in mediating the PNA rates. The DEA was found to increase upon Indigofera litterbag treatment where nos $Z$ were less abundant but interestingly in contrast to nirS denitrifiers strongly correlated with DEA. Though the short term litter application enhanced the nitrification and denitrification rates, low abundance but dominant role of $\operatorname{nos} Z$ denitrifiers while AOB as main actors in nitrification across lower Himalayan soil are important to be studied in long perspectives since these functional guilds may differentially impact the $\mathrm{N}$ cycling function and thus carry strong implications for overall environment.

Keywords: ecosystem services, nitrification, nosZ gene, AOA, Indigofera, Himalaya

\section{Introduction}

Soil formed at the inter-section of lithosphere, biosphere, atmosphere, and hydrosphere consists of major components including mineral, organic, liquid and gas. Beside regulating the majority of ecosystem processes at landscapes, it also provides a range of ecosystem services thus plays an important role in sustaining humanity [1]. It supports plant growth and provides nutrients such as nitrogen [2], involves in flood mitigation, filtration of nutrients, recycling and detoxification of waste and gaseous emissions and enable humans to live in a healthy environment [3]. In mountainous regions, soil is important for agriculture productivity but also impacts overall environment through rich biodiversity and several functions such as $\mathrm{N}$ cycling.

These regions are among the highly prone areas to be affected by the global warming which may ultimately leads to variations in structure and diversity of microbial community and even extinction of few species [4] and thus the associated functions. In mountainous regions, the plant litter through decay of plant biomass contributes to maintaining the nutrient transformations and is critical in shaping the various forms of nutrients and substrates for hosted microbial communities [5]. This along with changing climate has a very significant impact on soil processes and therefore on the provision of ecosystem services [3]. Moreover, human perturbations including fires, fertilization and land-use changes has substantially altered the soil properties and subsequent nutrient fluxes hence contribute to climate change events. For example, the IPCC assessment reports have estimated a rise of up to $2^{\circ} \mathrm{C}$ in average global temperatures by the end of the century [6]. Such increased temperatures may also stimulate the nitrogen availability in soil contributing to increased amount of greenhouse gases [7] which may affect soil and overall environment [8]. Such impacts of climate change are expected to be severe particularly in arid and semiarid areas [9]. The altered nutrient cycling and the frequency, intensity and duration of the extreme climatic events have increased substantially especially during the $21^{\text {st }}$ century hence may impact overall ecosystems [10].
$\mathrm{N}$ cycling in these soil ecosystems is important keeping in view the soil fertility perspectives but is also crucial from environmental quality perspectives such as $\mathrm{N}$ losses. For example, the nitrous oxide emissions through soils can contribute to global warming phenomenon having climate changes implications. In $21^{\text {st }}$ century the mountainous regions are particularly expected to experience the extreme exposure to climate change affecting soils and residing communities. The projected increase in warming and intense precipitation [11] may also affect the soil productivity and biogeochemical cycling. For example, an increase in temperature could enhance the $\mathrm{N}_{2} \mathrm{O}$ emissions from ecosystems through impact on nitrification and denitrification processes and the ratio of $\mathrm{N}_{2} \mathrm{O} / \mathrm{NO}_{3}^{-}$ [12]. Nitrogen fertilization regimes have increased the $\mathrm{N}$ losses through $\mathrm{N}$ leaching, and volatilization thus affected the environment through global warming, and eutrophication etc. [13]. Since pre-industrial times atmospheric $\mathrm{N}_{2} \mathrm{O}$ concentrations have increased by $19 \%$ [14] while an increase in soil nitrates has also triggered the $\mathrm{N}$ leaching hence ground water pollution [15].

In face of such climate change events the uneven precipitation may lead to increased soil organic carbon storage particularly in Himalaya region [16]. Such severe impacts need crucial management measures through increasing the adaptive capacity of farmers [17] and various mitigation strategies such as application of organic amendment to soils may contribute in slow release of nutrients and improving the soil health. The practice is also known to enhance the soil nutrient (carbon) stocks in degraded soils [18]. Plant litter may also increase the nutrient storage in soils hence improving the soil health. Such as the organic carbon added through amendments is an important indicator of soil quality which controls the soil physicochemical properties [19] but also enhances soil productivity [20] through increased availability of carbon and nitrogen [21]. Plant litter is a source of organic matter used in microbial decomposition [2], provided organic matter plays an important role in ecosystems by retaining and supplying plant nutrients, reducing soil erosion, and enhancing water holding capacity [18]. For example, the farming practices such as application of plant litter and use of green manure, composts and rotation with 
intercropping are believed to enhance soil nutrient sequestration [22].

These practices in $\mathrm{N}$ cycling perspectives may help to manage the $\mathrm{N}$ release to the environment. Impact of plant litter amendment to $\mathrm{N}$ cycling processes, nitrification and denitrification and the involved microbial communities (nitrifiers, denitrifiers) is therefore crucial to understand their long-term impact on $\mathrm{N}$ losses. The current work using litterbag adopted approach was carried out to assess the effects of plant litter (Pinus wallichiana and Indigofera heterantha) amendments on nitrification, denitrification, and involved microbial communities (ammonia oxidizing archaea and bacteria (AOA, AOB) and nirs, nosZ denitrifiers) in Abbottabad, lower Himalaya.

\section{Materials and Methods}

\section{Experimental Setup}

Soil incubation experiment was conducted with RCBD plotted at the field farm of COMSATS Abbottabad (34 ${ }^{\circ} 11^{\prime} 57.13^{\prime \prime} \mathrm{N}$ latitude, 73¹4'50.00'” E longitude) with litter bag treatments. Litterbag is a standard apparatus used in plant litter decomposition studies [23]. The experiment was performed in three replicates with two factors, three treatments and three sampling dates including control, hence we randomized each factor in each block. Polyester litter bags with dimensions of $20 \times 20 \mathrm{~cm}\left(0.04 \mathrm{~m}^{2}\right)$ were filled with dried and chopped litter with following treatments; Indigofera heterantha (I), Pinus wallichiana (P), Pinus wallichiana \pm Indigofera heterantha (PI), litter of these plants was selected since these species are native to the studied region - lower Himalaya. The fourth treatment was control and was without any application of plant litter. There were three sampling dates, 7, 15 and 28 days for taking samples for further analyses. Each treatment was provided with 3 replicates and the total of 27 bags were prepared. The field experiment was set in $304.8 \times 243.84 \mathrm{~cm}$ plot using randomized complete block design where the plot was divided into three blocks (4 columns and 3 rows each).

\section{Collection and Preparation of Plant Litter}

Litter from Pinus wallichiana and Indigofera heterantha was collected from Bagnotar near Abbottabad. After collection, the plant material was air dried to constant mass for 15 days. The stems and leaves were separated and cut into $2-4 \mathrm{~cm}$ length and the proportion of each organ in each plant was determined. Then each sample was weighed to have 20 grams, in which the proportion of each organ (leaves and stems) was respected. Pine stem proportion was $45 \%$ and leave proportion $55 \%$, Indigofera stem proportion was $58 \%$ and leaves $42 \%$, the mixture proportion was respected. The Pine \pm Indigofera sample was prepared on 1:1 ratio on weight basis, and again in the Pine \pm Indigo, the proportion of each organ for each plant was respected.

\section{Litter and Soil Sampling and Chemical Analysis}

Litter and soil samples were collected from the experimental site after 7 days of burying litterbags at $5 \mathrm{~cm}$ soil depth followed by 15- and 28-day intervals. Soil $\mathrm{pH}$ was determined in 1:5 (w/v) soil: water suspensions with a $\mathrm{pH}$ meter, after equilibration for 1 hour. Soil collected locally from the field farm of COMSATS Abbottabad was loamy in texture (sand 52\%, silt 29\%, 19 clay \%), EC $0.81 \mathrm{~d} \mathrm{~S} \mathrm{~m}^{-1}$ with $7.8 \mathrm{pH}$ and average moisture contents of $28 \%$. Soil moisture content was measured by weighing $5 \mathrm{~g}$ of fresh soil after sampling and dried in oven at $105^{\circ} \mathrm{C}$ for $24 \mathrm{hrs}$. Soil $\mathrm{NO}_{3}^{-}-\mathrm{N}$ was measured after sampling. The moisture contents in soil samples were adjusted by oven drying of few grams of soil. Stock solution of nitrate was prepared after drying potassium nitrate $\left(\mathrm{KNO}_{3}\right)$ in an oven at $105^{\circ} \mathrm{C}$ for $24 \mathrm{hrs} .1 \mathrm{~g} \mathrm{KNO}_{3}$ was dissolved in water and diluted to $1000 \mathrm{ml}$. From the stock solution, $\mathrm{NO}_{3}{ }^{-}$standards were prepared as $0,2,4,6,8$ and 10 ppm. $10 \mathrm{~g}$ soil was mixed with $100 \mathrm{ml}$ distilled water and shaken for $1 \mathrm{~h}$. Then the sample was filtered, $50 \mathrm{~mL}$ clear sample was added with $1 \mathrm{~mL} 1 \mathrm{~N} \mathrm{HCl}$ and mixed properly. The absorbance from the UV visible spectrophotometer was read at $220 \mathrm{~nm}$. A regression plot was drawn to determine the concentration of nitrate in soil samples and data were statistically analyzed using Statview software (SAS 1999).

\section{Extraction and Preparation of Nucleic Acid} (DNA)

Three independent DNA extractions were performed for each frozen soil subsamples using the PowerSoil DNA Isolation Kit (MO BIO Laboratories), according to the protocol of the manufacturer. The concentration of the soil DNA was determined by putting the known concentrations on the gel and the samples were diluted to run further analyses accordingly as detailed below.

\section{Gene Abundances of Nitrifiers and Denitrifiers Communities}

The abundance of nitrifiers and denitrifiers were estimated by quantitative PCR assays carried out as described previously [24]. The final reaction volume was $25 \mu \mathrm{l}$ for nirS and nos $Z$ with $1 \mu \mathrm{M}$ for nirS and nos $Z$ of forward and reverse primers; $12.5 \mu \mathrm{L}$ of QuantiTect $\mathrm{SYBR}^{\circledR}$ Green I PCR kit (Qiagen) for nirS and nosZ; $0.5 \mu \mathrm{g}$ and $0.4 \mu \mathrm{g}$ of T4 protein (Qbiogene, Carlsbad, CA USA) for nirS and nos $Z$ respectively. Standard curves 
for nirS and nosZ were obtained by performing qPCR assay on serial dilutions of known amount of plasmid DNA containing the targeted gene (from $10^{7}$ to $10^{1}$ copies). Microbial community quantification was carried out as described previously [24]. The genes encoding enzymes involved in ammonia-oxidation (amoA) for both bacteria and archaea were quantified to know the size of bacterial (AOB) and archaeal (AOA) ammoniaoxidizers in studied samples where the method and thermocycler conditions were as described by [25] and [15]. Independent qPCR assays were performed for each sample and the mean was calculated accordingly.

\section{Potential Nitrification Activity}

Fresh soil samples were used to quantify the potential nitrification activity (PNA) as described previously [26]. Briefly, $4 \mathrm{~g}$ fresh soil weighing about $2.5 \mathrm{~g}$ dry soil was mixed with $10 \mathrm{ml}$ reagent solution and suspensions were shaken at $175 \mathrm{rpm}$ in orbital shaker. After 1, 8, 24 and 48 hours, $2 \mathrm{ml}$ liquid suspension was taken, and ammonium oxidation was blocked using $2 \mathrm{ml} \mathrm{KCl}(2 \mathrm{M})$ and afterward centrifugation at $3000 \mathrm{rpm}$ for 2 minutes. Recovered supernatant solution was put in bottles and stored in freezer at $4^{\circ} \mathrm{C}$. Then at the end $0.8 \mathrm{ml}$ supernatant was added with $1.5 \mathrm{ml} \mathrm{NH} \mathrm{Nl}_{4} \mathrm{Cl}$ buffer and $0.4 \mathrm{ml}$ Diazzo solution. After 30 minutes absorbance was measured against the standards at $530 \mathrm{~nm}$ wavelength using UV/VIS Spectrophotometer afterwards potential nitrification activity was calculated as $\mu \mathrm{g} \mathrm{NO}_{2}-\mathrm{N} \mathrm{h}^{-1}$.

\section{Denitrification Enzyme Activity}

Denitrification enzyme activity (DEA) was quantified through incubation of fresh soil in the airtight plasma for $4 \mathrm{~h}$ at room temperature and $\mathrm{N}_{2} \mathrm{O}$ was measured every half hour for a period of $2 \mathrm{~h}$ with 4 readings in total, on a $\mathrm{GC}$ following the principle as detailed previously [27]. The soil in plasma contained the substrate and the conditions in plasma were anaerobic to block the last step of denitrification process to allow the $\mathrm{N}_{2} \mathrm{O}$ accumulation [28].

\section{Statistical Analysis}

The obtained data for community abundances and enzyme activities were statistically analyzed. A linear model equation was used for calculation of microbial enzyme activities which were also analyzed through Statview to know the differences among treatments. The acquired data in three replicates for different variables were analyzed through Student's t test $(\mathrm{p}<0.05)$ and an ANOVA test as required by using Statview software (SAS 1999).

\section{Results}

Soil Physicochemical Properties

Soil characteristics including soil moisture, $\mathrm{pH}$ and nitrate concentrations observed during the experiment

Table 1. Plant litter, percent moisture, soil nitrates and $\mathrm{pH}$ among different treatments and sampling days.

\begin{tabular}{|c|c|c|c|c|}
\hline Sampling Days & Treatments & Percent moisture & Soil pH & Soil $\mathrm{NO}_{3}-\mathrm{N}(\mathrm{mg} / \mathrm{kg})$ \\
\hline \multirow{4}{*}{0} & Control & - & 7.8 & $5.1 \pm 1.6$ \\
\hline & Pine & $10 \pm 0.06$ & 7.8 & - \\
\hline & Indigofera & $10 \pm 0.05$ & 7.8 & - \\
\hline & Pine + Indigofera & $10 \pm 0.06$ & 7.8 & - \\
\hline \multirow{4}{*}{7} & Control & - & 7.8 & $9.0 \pm 1.3$ \\
\hline & Pine & $99.89 \pm 18.5$ & 7.2 & $4.7 \pm 0.06$ \\
\hline & Indigofera & $117 \pm 8.2$ & 7.2 & $5.4 \pm 0.63$ \\
\hline & Pine + Indigofera & $115.1 \pm 16$ & 7.1 & $4.2 \pm 1.29$ \\
\hline \multirow{4}{*}{15} & Control & - & 7.8 & $7.0 \pm 0.2$ \\
\hline & Pine & $94 \pm 10.4$ & 8.1 & $5.7 \pm 1.22$ \\
\hline & Indigofera & $133.3 \pm 28.8$ & 8.1 & $5.4 \pm 2.3$ \\
\hline & Pine + Indigofera & $144.4 \pm 77$ & 7.8 & $6.1 \pm 2.26$ \\
\hline \multirow{4}{*}{28} & Control & - & 7.8 & $11.5 \pm 0.75$ \\
\hline & Pine & $154 \pm 5.4$ & 7.6 & $10.7 \pm 1.50$ \\
\hline & Indigofera & $131.6 \pm 2.4$ & 7.8 & $9.0 \pm 1.18$ \\
\hline & Pine + Indigofera & $135 \pm 4.8$ & 7.9 & $10.2 \pm 0.86$ \\
\hline
\end{tabular}


are summarized in Table 1 . Soil $\mathrm{pH}$ was 7.8 at day 0 and a slight drop of 0.6 unit observed after the plant litter treatment at 7 days, while there was an increase of 0.9 units observed on day 15 in Pine and indigofera treatments and Pine + indigofera gained 0.6 units. The $\mathrm{pH}$ at day 28 remained closer to day 0. Soil nitrates, depict the nitrification rates but also act as substrate for denitrification, were recorded differently for various treatments. For example, the nitrate concentrations at the start of experiment were $5.1 \mathrm{mg} / \mathrm{kg}$ and after addition of plant litter it remained around 4.7, 5.4 and $4.2 \mathrm{mg} / \mathrm{kg}$ for pine, indigofera and Pine + Indigofera treatments respectively, where the $\mathrm{NO}_{3}^{-}$in control showed the highest concentration at day 28 after sampling and the lowest on day 15. The pine litterbag application showed the highest nitrate concentration on day 28 while the lowest on day 7. Interestingly, an increase in $\mathrm{NO}_{3}^{-}$concentration after application of indigofera litter was observed from day 0 to day 7 in comparison to initial concentration. In contrast, the application of Pine and Pine + Indigo litter resulted in a decrease in $\mathrm{NO}_{3}{ }^{-}$concentration during the $1^{\text {st }}$ week of experiment (Table 1). On basis of this observation the quantifications of the genes encoding the enzymes for nitrification and denitrification processes were carried out for the treatments applied with Indigofera litter.

\section{Potential Nitrification Activity (PNA) Across Various Litter Bag Treatments}

Potential nitrification activity (PNA) was found to be increasing with the experiment time of plant litter application with high values for the treatments with litter as compared to control (Fig. 1) Overall the rates of the PNA were higher after 28 days in comparison to initial and ranged from 0.025 to $0.034 \mu \mathrm{g} \mathrm{NO} \mathrm{NO}_{2}-\mathrm{N}$ per $\mathrm{g}$ dry soil for Indigofera litter treatment in contrast to control which remained $0.08 \mu \mathrm{g} \mathrm{NO}_{2}-\mathrm{N}$ per g dry soil. The addition of indigofera plant litter resulted in PNA as $0.1,0.21,0.21 \mu \mathrm{g} \mathrm{NO}_{2}-\mathrm{N}$ per $\mathrm{g}$ dry soil at day 7 , 15 and 28, respectively. It was also observed that the increase in PNA continued for overall duration, but this increase was stronger at initial days. For example, the change in PNA was significant at day 7 and 15 in comparison to control whereas with respect to day 15 , a non-significant difference at day $28(\mathrm{p}<0.05)$ was observed (Fig. 2, Fig. 3).

\section{Denitrification Enzyme Activity (DEA) Across Various Litter Bag Treatments}

Similar to the observations for PNA, the denitrification enzyme activity was found to be significantly higher for the litter bag treatments as compared to the control. However, this increase was prominent with experiment time where the highest values for DEA were observed after 28 days of litter application. As shown in the Fig. 3, the indigofera plant litter caused an increased DEA with values recorded as $0.022,0.27,0.038 \mu \mathrm{gN}-\mathrm{N}_{2} \mathrm{O} / \mathrm{g}$ dry soil at day 7,15 and 28, respectively. Although the increase in PNA was sharp just after the day 7, the trend for the DEA was relatively different with slight increase at earlier days but the highest values for the DEA at day 28 denote that the application of the litter has caused a significant increase in DEA where it overall ranged from 0.022 to $0.038 \mu \mathrm{g} \mathrm{N} \mathrm{N}_{2} \mathrm{O}-\mathrm{N}$ per $\mathrm{g}$ dry soil for the Indigofera treatment while in control it was $0.021 \mu \mathrm{g} \mathrm{N}_{2} \mathrm{O}-\mathrm{N}$ per g dry soil.

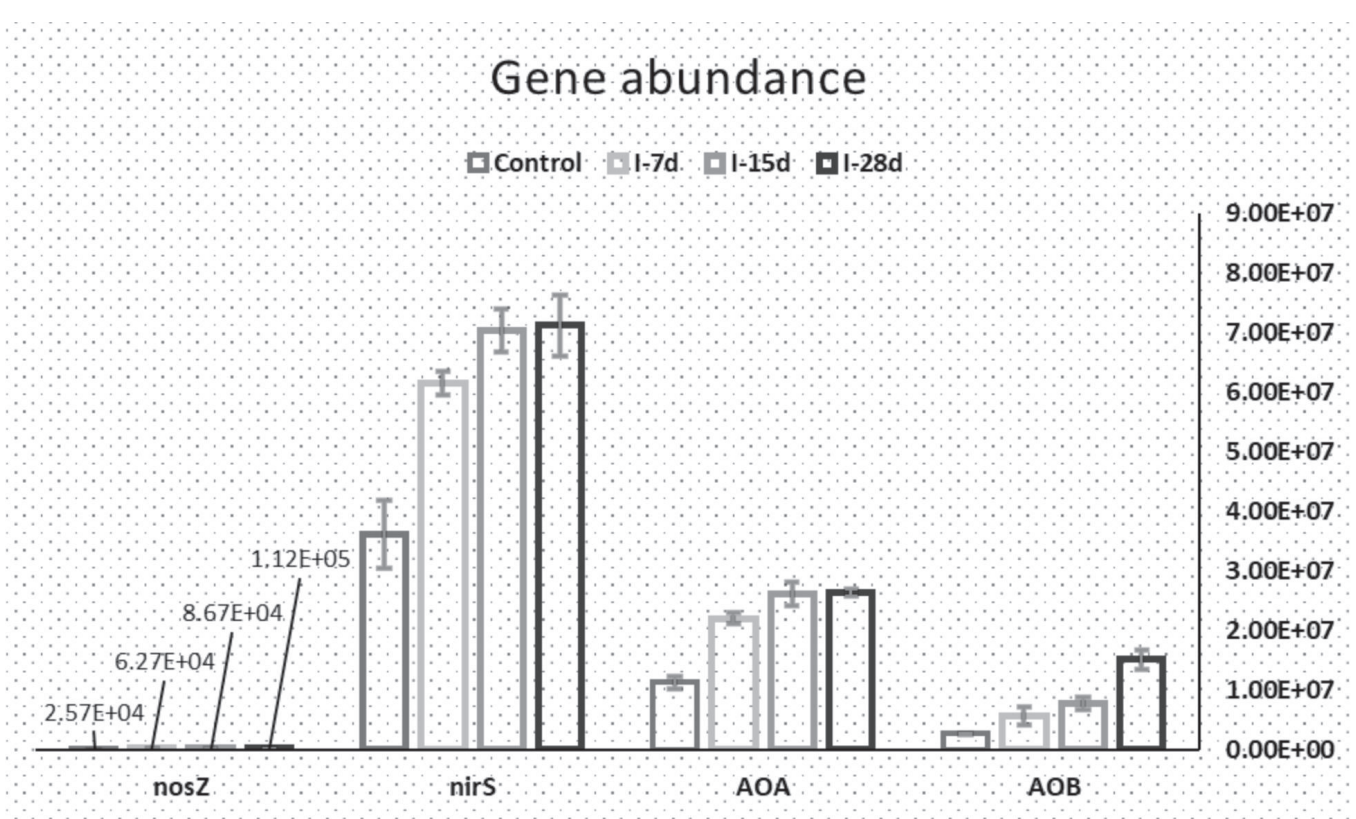

Fig. 1. The community gene abundance of nitrifiers (archaeal and bacterial amoA (AOA and $\mathrm{AOB}$ )) and denitrifiers (nir $\mathrm{S}$ and nosZ) in number of gene copes per ng DNA. 
nosZ

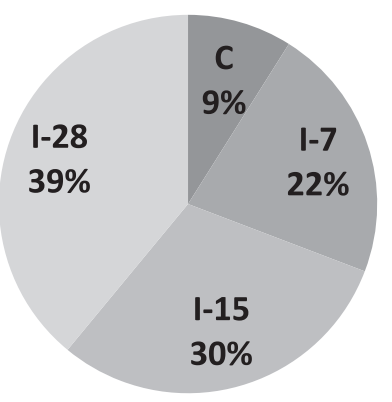

AOA

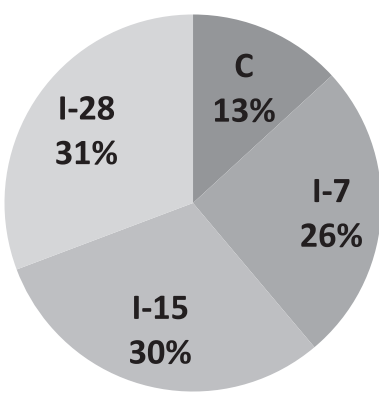

DEA

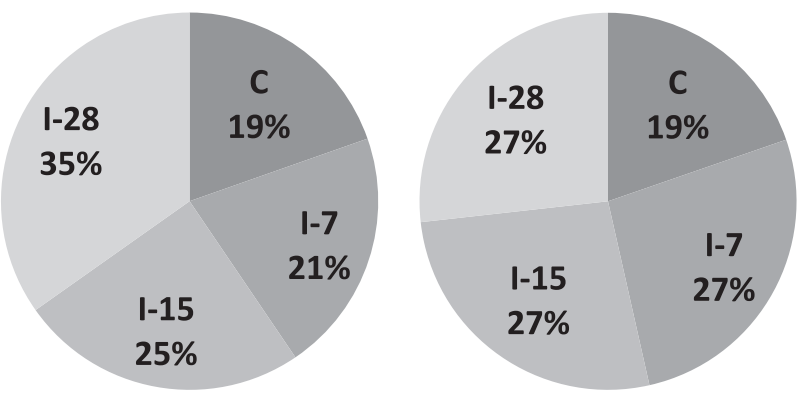

Fig. 2. Treatment wise percent distribution of nitrification and denitrification processes and the size of nitrifying and denitrifying communities for initial to 28 days sampling for control, I-7, I-15 and I-28 days.

\section{Community Gene Abundances of Nitrifiers (amo $A$ Gene)}

The size of the ammonia oxidizers controlling the nitrification process are described by the number of gene copies of the amo $A$ genes in ammonia oxidizing archaea (AOA) and ammonia oxidizing bacteria (AOB) per ng of DNA which we have assessed by quantifying the archaeal and bacterial ammonia monooxygenase gene through qPCR as shown in (Fig. 1). The abundances of AOA ranged from $1.13 \mathrm{E}+07$ to $2.63 \mathrm{E}+07$ while the abundance of $\mathrm{AOB}$ ranged from $2.77 \mathrm{E}+06$ to $1.51 \mathrm{E}+07$ per ng DNA. The abundances of these nitrifying functional guilds were
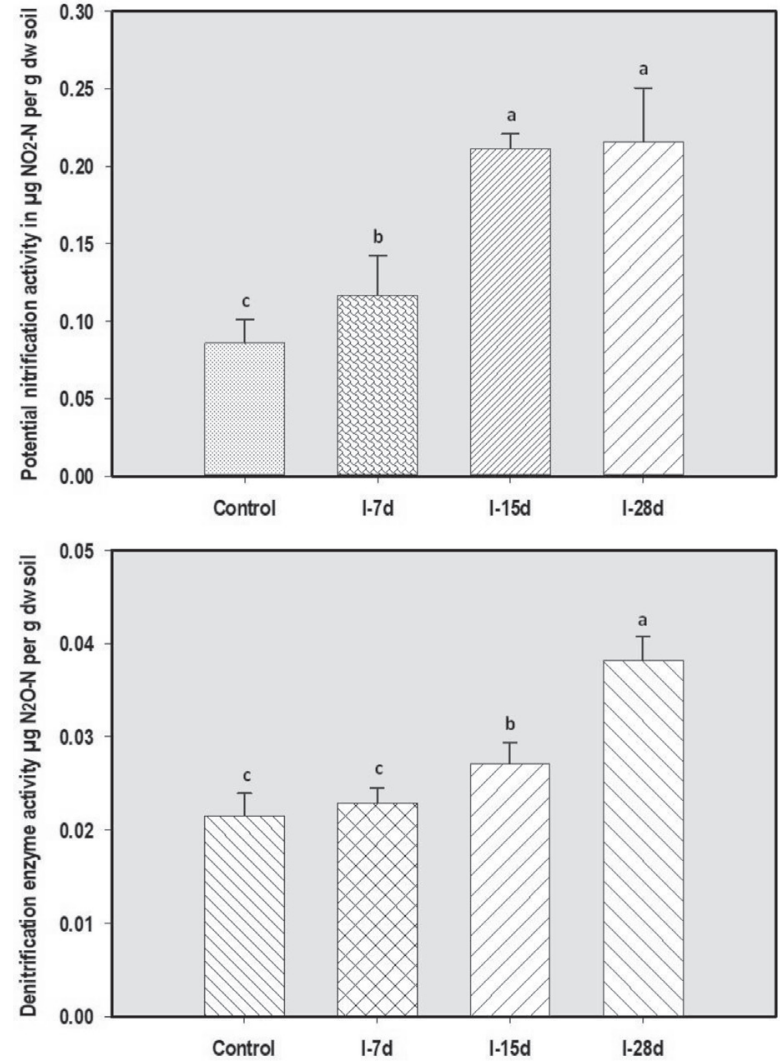

Fig. 3. Potential nitrification activity (PNA) and denitrification enzyme activity (DEA) in $\mu \mathrm{g} \mathrm{NO}_{2}-\mathrm{N}$ and $\mu \mathrm{g} \mathrm{N}_{2} \mathrm{O}-\mathrm{N}$ per $\mathrm{g}$ dry weight soil per h, respectively at various sampling days (Control, I-7, I-15 and 28). Each bar represents the mean of different replicates $(n=3)$.

recorded higher at all days-intervals as compared to control. Overall, the size of AOA community was significantly higher in indigofera treatment as compared to AOB community. The gene abundance of the AOA ranged from $2.20 \mathrm{E}+07$ to $2.63 \mathrm{E}+07$ gene copies $\mathrm{ng}^{-1}$ DNA for indigofera treatment which was higher than control while the size of AOB community ranged from $5.63 \mathrm{E}+06$ to $1.51 \mathrm{E} \pm 07$ gene copies $\mathrm{ng}^{-1} \mathrm{DNA}$, for indigofera treatment, in contrast to control which was $2.77 \mathrm{E}+06$ gene copies $\mathrm{ng}^{-1}$ DNA. Overall, the abundance of the AOA was observed higher than the $\mathrm{AOB}$ but for both the control was always less than the treatments showing that the application of plant litter has significantly increased the community enrichment both for AOA and AOB.

\section{Community Gene Abundances of Denitrifiers (nirS, nosZ Gene)}

The results of gene abundances showed that nirS ranged from $6.15 \mathrm{E}+07$ to $7.12 \mathrm{E}+07$ gene copies $\mathrm{ng}^{-1}$ DNA for indigofera treatment and 3.62E +07 gene copies $\mathrm{ng}^{-1}$ DNA for control while, the abundance of nos $\mathrm{Z}$ ranged from $6.27 \mathrm{E}+04$ to $1.12 \mathrm{E}+05$ gene copies 
$\mathrm{ng}^{-1}$ DNA for indigofera treatment and $2.57 \mathrm{E}+04$ gene copies $n^{-1}$ DNA for control (Fig. 1). Although the nirS denitrifiers were always significantly higher $(p<0.05)$ even for the control at start of the experiment time but this was found increasing with time throughout the experiment for all the days intervals with the highest values for abundance of nirS denitrifiers at day 28. Overall, it was observed that the addition of the indigofera might have resulted in enrichment of $n i r S$ denitrifiers. In contrast, the nos $Z$ denitrifiers were recorded, less abundant which were later increased over time, but the size remained low than the nirS, throughout the experiment highlighting that the nos $Z$ communities were significantly low $(p<0.05)$ in number with or without application of plant litter. We found that size of nirS ranged from 1.97E + 06, 3.63E +06 and $5.13 \mathrm{E}+06$ gene copies per ng DNA for day 7, 15 and 28 , respectively while the nos Z ranged from $2.57 \mathrm{E}+04$ to $1.12 \mathrm{E}+05$ gene copies $\mathrm{ng}^{-1} \mathrm{DNA}$.

\section{Correlation Analyses of N Cycling Processes and Litter Bag Treatments}

To understand the relation between the community gene abundances and the nitrification and denitrification enzyme activities, we carried out the correlation analyses between the PNA and DEA and sizes of the nitrifiers (AOA, AOB) and the denitrifiers (nirS, nos $Z$ ). The correlation analyses showed that PNA was positively correlated to the size of both bacterial and archaeal nitrifiers however this correlation was stronger for the AOB $(\mathrm{r}=0.59, \mathrm{p}<0.05)$ as compared to AOA $(\mathrm{r}=0.43, \mathrm{p}<0.05)$ representing that both type of nitrifiers were involved in nitrification process. The correlation analyses of the denitrification enzyme activity and the abundances of denitrifiers showed a positive correlation between the studied denitrifying communities and the DEA. However, this correlation was relatively stronger for the $\operatorname{nos} Z(\mathrm{r}=0.79, \mathrm{p}<0.05)$ denitrifiers and compared to $\operatorname{nir} S(\mathrm{r}=0.46, \mathrm{p}<0.05)$. Although the size of the nos $Z$ denitrifiers was less as shown by the gene abundance data but the correlation analyses revealed a stronger relation of the DEA with the nosZ denitrifiers.

\section{Discussion}

Ecosystem services provided by soil and the residing microbial communities are crucial on earth [29]. N cycling in soil is mainly driven through nitrification and denitrification process thus control the $\mathrm{N}$ losses [30] where these processes upon fertilization and organic amendments are important from ecological perspectives for example in mountainous regions with various types of plant litter added to the ecosystems [31]. Here we investigated the $\mathrm{N}$ cycling processes upon plant litter addition to soil in lowe Himalayas.

Results showed an increase in soil $\mathrm{NO}_{3}{ }^{-}$concentration over the experiment time as compared to initial value at day 0 and up till day 7 upon addition of indigofera litter. However, a decrease in $\mathrm{NO}_{3}^{-}$concentration was observed for pine and pine + indigo treatments during the first week. This could also be attributed to the linear $\mathrm{N}$ mineralization in control which might be produced due to the decomposition of native soil organic matter while the increase in $\mathrm{NO}_{3}{ }^{-}$concentration in indigofera treatment may be associated to its high $\mathrm{C}: \mathrm{N}$ ratio since the indigofera belongs to leguminous group which is rich in nitrogen as observed previously [32]. Similarly, the decrease in nitrate concentration could be attributed to humid conditions with high plant litter $\mathrm{C} / \mathrm{N}$ ratio as submerged conditions may support the denitrification activity [33], meanwhile plant litter usually high in C:N ratio may acts as substrates for microbes [34] which may also support $\mathrm{NO}_{3}$ utilization resulting in increased denitrification [35]. The significant decrease in $\mathrm{NO}_{3}^{-}$ for control treatment at day 15 may also be attributed to leaching phenomenon. It is pertinent to mention here that the precipitation occurred at day 8 and 9 might have triggered the leaching of the nitrate ultimately resulting in decreased soil nitrates. Overall, addition of plant litter like indigofera being leguminous family may cause high mineralization rates and this high plant nitrogen may contribute to the differences in $\mathrm{N}$ transformation processes [36]. Plant litter may also contribute favorably to microbial community abundance and activity and accelerates the $\mathrm{N}$ mineralization since the litter addition can promote the reduced $\mathrm{NO}_{3}-\mathrm{N}$ losses than that of un-amended conditions [5]. In contrast, plant biomass with low $\mathrm{N}$ contents may negatively influence the plant available $\mathrm{N}$ through accelerated nitrogen immobilization [37]. Nitrates deficiency can also be referred to low denitrification activity whereas high nitrates and denitrification occurring in a system directly linked to the fact that the denitrification may serve as a sink for the net nitrification [36]. We observed that the plant litter significantly influenced both the PNA and DEA and corresponding gene with PNA followed a trend of sharp increase from start to day 28, where DEA was also increasing with time. The gene abundance of nos $Z$ and nirS were increased since the application of plant litter with days (i.e. Control, I-7, I-15, I-28) where the minimum number of gene copies $(2.57 \mathrm{E}+04$ per ng DNA) were observed in control and maximum after litter addition $(1.12 \mathrm{E}+05)$ at day 28 (Fig. 1, Fig. 2). The increase in nos $Z$ gene abundance upon litter application may also hint the reduction of $\mathrm{N}_{2} \mathrm{O}$ to $\mathrm{N}_{2}$ as nos $Z$ is involved in this step [38]. Overall, nirS dominated the denitrification gene pool implying that the final product of denitrification in this case might be the nitrous oxide thus completing the cycle [39].

The indigofera litter addition induced an increase in the size of bacterial amoA throughout the experiment at various sampling days and such observations about the stimulatory effects of plant litter addition to soil have previously been reported [40]. In the current study, AOA dominated in community size as compared to AOB however the nitrification might have been 

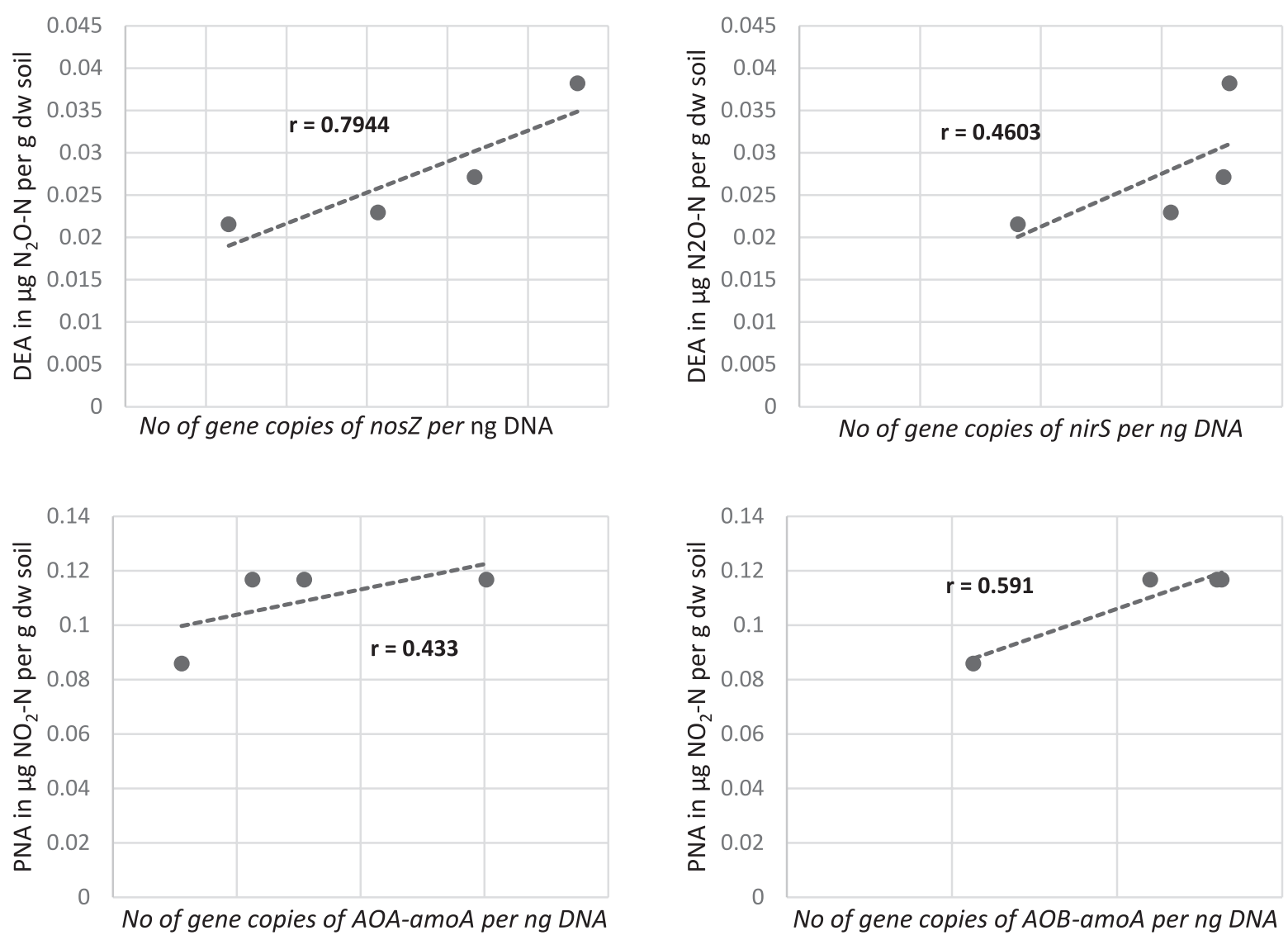

Fig. 4. Relationship between denitrification enzyme activity (DEA) to nosZ and nirS gene copies per ng DNA and potential nitrification activity (PNA) to amoA gene copies per ng DNA for bacteria and archaea.

controlled mainly by AOB as found through correlation analyses. In contrast, AOA are shown to be dominant nitrifying actors in stress or unusual environments like high temperature or constructed soils like Technosols $[24,41]$. Similarly, this has been reported that a range microbial communities are involved in different function due to functional redundancy but their role differentially impact the overall process [42]. Moreover, the microbial communities present in an ecosystem may also subject to the prevailing environmental conditions thus are likely to evolve in the context of micro-environment or changing environment [43]. The studied soil system might have been under changing climate events as reported for Himalaya and meanwhile the dominance of AOA is observed to be high in harsh environment as compared to AOB [44]. Previous studies have also shown that AOA are more abundant than bacterial amoA in a variety of environments including terrestrial ecosystems $[45,46]$. Overall, the trend for nitrifiers and denitrifiers community abundances was found to be positively increasing with experiment time. Such community enrichment may have happened owing to the greater number of carbon sources in indigofera treatment than control. Earlier, [47] reported that the organic amendment affected the microbial gene pool in the studied environment. In accordance to the gene abundance data, the correlation analyses showed a positive correlation between the PNA and both AOA and $\mathrm{AOB}$ where this relationship was found stronger for AOB $(r=0.59)$ than AOA $(r=0.43)$ (Fig. 4) as observed for AOB previously [24]. Similarly, a strong positive correlation between DEA and the abundance of nosZ denitrifiers was in line with earlier reports which proposed that the biological processes are positively correlated to the abundance of corresponding genes [48]. Moreover, the microbial communities often share similar ecological attributes which usually carry strong correlation to the ecosystem functioning [42]. It is pertinent to mention here that the addition of plant litter might have triggered the community enrichment between the AOA and $\mathrm{AOB}$, with $\mathrm{AOB}$ being the dominant actors for nitrification crucial in is estimating the overall nitrification rates [49]. In DEA nos $Z$ were less abundant, but due to their dominant role as shown by correlation analyses and involvement in reduction of $\mathrm{N}_{2} \mathrm{O}$ to $\mathrm{N}_{2}$ these are critical in deciding the overall nitrous oxide budget from soils $[38,50]$.

\section{Conclusions}

To conclude, the increased nitrification and denitrification enzyme activities and the abundances of the corresponding community genes gave us an insight 
into the $\mathrm{N}$ cycling processes but also the driving actors, upon plant litter - indigofera application, in studied soil in lower Himalaya. Positive correlation of nitrification with both $\mathrm{AOA}$ and $\mathrm{AOB}$ was found where $\mathrm{AOB}$ seems to be dominantly involved in nitrification in the studied soil. The nos $Z$ despite of being low in size are major actors in DEA and nitrous oxide reduction crucial in overall greenhouse gas budget. Long term studies, to investigate the shifts in community enrichment and associated processes in the studied region are needed to ultimately assess $\mathrm{N}$ cycling processes under changing climate scenarios.

\section{Acknowledgements}

This work was financially assisted by research grants provided by International Foundation for Science (IFS - C/5429-1) and Higher Education Commission (HEC - No: PD-IPFP/HRD/HEC/2013/3003) of Pakistan. This work was also funded by Researchers Supporting Project number (RSP 2019/121), King Saud University, Riyadh, Saudi Arabia.

\section{Conflict of Interest}

The authors declare no conflict of interest.

\section{References}

1. PEREIRA P., BOGUNOVIC I., MUNOZ-ROJAS M., BREVIK E.C. Soil ecosystem services, sustainability, valuation and management. Curr Opin Environ Sci. Health. 5, 7, 2017.

2. FAO. World's Soil Resources. Status of the World's Soil Resources. 650, 2015.

3. DOMINATI E., PATTERSON M., MACKAY A.A. Framework for classifying and quantifying the natural capital and ecosystem services of soils. Ecol Econ. 69 (9), 1858, 2010.

4. SHARMA V., DAHIYA D., VASANTH D. Characteristics of Microbial Community and Enzyme Activities in Higher Altitude Regions. In R. GOEL, R. SONI, D.C. SUYAL (Eds.). Microbiological Advancements for Higher Altitude Agro-Ecosystems \& Sustainability (pp. 201-226). Singapore: Springer Singapore. 2020.

5. YANG Y., ZHANG L., WEI X., CHEN Y., YANG W., TAN B., WU F. Litter removal reduced soil nitrogen mineralization in repeated freeze-thaw cycles. Scientific Reports. 9 (1), 1, 2019.

6. YURTSEVEN I., SERENGIL Y., GÖKBULAK F., ŞENGÖNÜL K., OZHAN S., KILIÇ U., OZÇELIK M.S. Results of a paired catchment analysis of forest thinning in Turkey in relation to forest management options. Sci. Total Environ. 618, 785, 2018.

7. TROY C., AVE L., STREET M.B.L., HOLE W. Effects of Temperature and Moisture Stress on Nitrous Oxide Production in Agricultural Soil. 1, 2011.

8. BREVIK E.C. Soils and Climate Change: Gas Fluxes and Soil Processes. Soil Horizons. 53 (4), 12, 2012.
9. MISRA A.K. Climate change and challenges of water and food security. Int. J. Sustain. Built Environ. 3 (1), 153, 2014.

10. YENI F., ALPAS H. Vulnerability of global food production to extreme climatic events. Food Res. Int. 96, 27, 2017.

11. REN G.Y., SHRESTHA A.B. Climate change in the Hindu Kush Himalaya. Advances in Climate Change Research. 8 (3), 137, 2017.

12. BENOIT M., GARNIER J., BILLEN G. Temperature dependence of nitrous oxide production of a luvisolic soil in batch experiments. Process Biochemistry. 50 (1), 79, 2015.

13. NEMECEK T., HAYER F., BONNIN E., CARROUÉE B., SCHNEIDER A., VIVIER C. Designing eco-efficient crop rotations using life cycle assessment of crop combinations. Eur. J. Agron. 65, 40, 2015.

14. BUTTERBACH-BAHL K., BAGGS E.M., DANNENMANN M., KIESE R., ZECHMEISTERBOLTENSTERN S. Nitrous oxide emissions from soils: how well do we understand the processes and their controls? Philos. T. R. Soc. B. 368 (1621), 20130122, 2013.

15. LEININGER S., URICH T., SCHLOTER M., SCHWARK L., QI J., NICOL G.W., SCHLEPER C. Archaea predominate among ammonia-oxidizing prokaryotes in soils. Nature. 442, 806, 2006.

16. LONGBOTTOM T.L., TOWNSEND-SMALL A., OWEN L.A., MURARI M.K. Climatic and topographic controls on soil organic matter storage and dynamics in the Indian Himalaya: Potential carbon cycle-climate change feedbacks. CATENA. 119, 125, 2014.

17. KARIMI V., KARAMI E., KESHAVARZ M. Climate change and agriculture: Impacts and adaptive responses in Iran. J. Integr. Agric. 17 (1), 1, 2018.

18. RYALS R., KAISER M., TORN M.S., BERHE A.A., SILVER W.L. Impacts of organic matter amendments on carbon and nitrogen dynamics in grassland soils. Soil Biol. Biochem. 68, 52, 2014.

19. REEVES D.W. The role of soil organic matter in maintaining soil quality in continuous cropping systems. Soil Till. Res. 43 (1), 131, 1997.

20. PLACEK A., GROBELAK A., HILLER J., STEPIEŃ W., JELONEK P., JASKULAK M., KACPRZAK M. The role of organic and inorganic amendments in carbon sequestration and immobilization of heavy metals in degraded soils. Journal of Sustainable Development of Energy. Water and Environment Systems. 5 (4), 509, 2017.

21. BHATTACHARJYA S., BHADURI D., CHAUHAN S., CHANDRA R., RAVERKAR K.P., PAREEK N. Comparative evaluation of three contrasting land use systems for soil carbon, microbial and biochemical indicators in North-Western Himalaya. Ecological Engineering. 103, 21, 2017.

22. GOH K.M. Greater mitigation of climate change by organic than conventional agriculture: A review. Biological Agriculture and Horticulture. 27 (2), 205, 2011.

23. LECERF A. Methods for estimating the effect of litterbag mesh size on decomposition. Ecological Modelling. 362, 65, 2017.

24. HAFEEZ F., SPOR A., BREUIL M.C., SCHWARTZ C., MARTIN-LAURENT F., PHILIPPOT L. Distribution of bacteria and nitrogen-cycling microbial communities along constructed Technosol depth-profiles. J. Hazard. Mater. 231, 88, 2012.

25. TOURNA M., FREITAG T.E., NICOL G.W., PROSSER J.I. Growth, activity and temperature responses of ammonia- 
oxidizing archaea and bacteria in soil microcosms. Environmental Microbiology. 10 (5), 1357, 2008.

26. HOFFMANN H., SCHLOTER M., WILKE B.M. Microscale-scale measurement of potential nitrification rates of soil aggregates. Biol. Fertil. Soils. 44 (2), 411, 2007.

27. DASSONVILLE N., GUILLAUMAUD N., PIOLA F., MEERTS P., POLY F. Niche construction by the invasive Asian knotweeds (species complex Fallopia): impact on activity, abundance and community structure of denitrifiers and nitrifiers. Biological Invasions. 13 (5), 1115, 2011.

28. YOSHINARI T., HYNES R., KNOWLES R. Acetylene inhibition of nitrous oxide reduction and measurement of denitrification and nitrogen fixation in soil. Soil Biol. Biochem. 9 (3), 177, 1977.

29. BENDER S.F., WAGG C., van der HEIJDEN M.G.A. An Underground Revolution: Biodiversity and Soil Ecological Engineering for Agricultural Sustainability. Trends Ecol Evol. 31 (6), 440, 2016.

30. YANG Y., ZHANG H., SHAN Y., WANG J., QIAN X., MENG T., CAI Z. Response of denitrification in paddy soils with different nitrification rates to soil moisture and glucose addition. Sci. Total Environ. 651, 2097, 2019.

31. OLIVEIRA U., MEGALI A.A., VASCONCELLOS A. Aerial plant biomass and litterfall as local determinants of leaf litter and fine root decomposition in a semiarid ecosystem of the Neotropical region. Arid Land Res. Manag. 33 (4), 375, 2019.

32. TRINSOUTROT I., NICOLARDOT B., JUSTES E., RECOUS S. Decomposition in the field of residues of oilseed rape grown at two levels of nitrogen fertilisation. Effects on the dynamics of soil mineral nitrogen between successive crops. Nutr Cycl Agroecosys. 56 (2), 125, 2000.

33. WANG S., WANG W., ZHAO S., WANG X., HEFTING M.M., SCHWARK L., ZHU G. Anammox and denitrification separately dominate microbial N-loss in water saturated and unsaturated soils horizons of riparian zones. Water research. 162, 139, 2019.

34. ABBASI M.K., KHALIQ A. Nitrogen Mineralization of a Loam Soil Supplemented with Organic-Inorganic amendments under Laboratory Incubation. Frontiers in Plant Science. 7 (July), 1. 2016.

35. NELSON M.B., BERLEMONT R., MARTINY A.C., MARTINY J.B.H. Nitrogen cycling potential of a grassland litter microbial community. Appl. Environ. Microb. 81 (20), 7012, 2015.

36. RICH J.J., HEICHEN R.S., BOTTOMLEY P.J., CROMACK K., MYROLD D.D. Community composition and functioning of denitrifying bacteria from adjacent meadow and forest soils. Appl. environ. microb. 69 (10), 5974, 2003.

37. MANZONI S., JACKSON R.B., TROFYMOW J.A., PORPORATO A. The global stoichiometry of litter nitrogen mineralization. Science. 321 (5889), 684, 2008.
38. JHA N., DESLIPPE J., SAGGAR S., TILLMAN R. GILTRAP D. Measuring bacterial denitrifier genes distribution and abundance in New Zealand dairy-grazed pasture soils. Accurate and efficient use of nutrients on farms. Occasional Report. 26, 1, 2013.

39. SAARENHEIMO J., RISSANEN A.J., ARVOLA L., NYKÄNEN H., LEHMANN M.F., TIIROLA M. Genetic and environmental controls on nitrous oxide accumulation in lakes. PLoS ONE. 10 (3), 1, 2015.

40. CHEN W.B., CHEN B.M., LIAO H.X., SU J.Q., PENG S.L. Leaf leachates have the potential to influence soil nitrification via changes in ammonia-oxidizing archaea and bacteria populations. Eur. J. Soil Sci. 71(1), 119, 2020.

41. HAFEEZ F., PHILIPPOT L., SPOR A., MARTINLAURENT F. Assessment of the resilience and resistance of remediated soils using denitrification as model process. J. Soils Sediments. 14 (1), 178, 2014.

42. LIU J., MENG Z., LIU X., ZHANG X.H. Microbial assembly, interaction, functioning, activity and diversification: a review derived from community compositional data. MLST. 1 (1), 112, 2019.

43. LOGUE J.B., FINDLAY S.E.G., COMTE J. Editorial: Microbial Responses to Environmental Changes. Front. Microbl. 6, 1364, 2015.

44. OSBORNE B.B., BARON J.S., WALLENSTEIN M.D. Moisture and temperature controls on nitrification differ among ammonia oxidizer communities from three alpine soil habitats. Front Earth Sci. 10 (1), 1, 2016.

45. MASAHITO H., KANAKO T., MASANORI S. Various players in the nitrogen cycle: Diversity and functions of the microorganisms involved in nitrification and denitrification. Soil Sci. Plant Nutr. 54 (1), 33, 2007.

46. DI H.J., CAMERON K.C., SHEN J.P., WINEFIELD C.S., O'CALLAGHAN M., BOWATTE S., HE J.Z. Ammoniaoxidizing bacteria and archaea grow under contrasting soil nitrogen conditions. FEMS Microbiol. Ecol. 72 (3), 386, 2010.

47. YUAN H.Z., ZHU Z.K., WEI X.M., LIU S.L., PENG P.Q., GUNINA A., WANG J.R. Straw and biochar strongly affect functional diversity of microbial metabolism in paddy soils. J. Integr. Agric. 18 (7), 1474, 2019.

48. ROCCA J.D., HALL E.K., LENNON J.T., EVANS S.E., WALDROP M.P., COTNER J.B., WALLENSTEIN M.D. Relationships between protein-encoding gene abundance and corresponding process are commonly assumed yet rarely observed. ISME J. 9 (8), 1693, 2015.

49. CLARK D.R., MCKEW B.A., DONG L.F., LEUNG G., DUMBRELL A.J., STOTT A., WHITBY C. Mineralization and nitrification: Archaea dominate ammonia-oxidising communities in grassland soils. Soil Biol. Biochem. 143, 107725, 2020.

50. ZHAO S., ZHOU J., YUAN D., WANG W., ZHOU L., PI Y., ZHU G. NirS-type $\mathrm{N}_{2} \mathrm{O}$-producers and nosZ II-type $\mathrm{N}_{2} \mathrm{O}$-reducers determine the $\mathrm{N}_{2} \mathrm{O}$ emission potential in farmland rhizosphere soils. J. Soils Sediments. 20 (1), 461, 2020. 